\title{
Evaluation of Bcl-2, Bcl-x and Cleaved Caspase-3 in Malignant Peripheral Nerve Sheath Tumors and Neurofibromas
}

\author{
KARIN S. CUNHA ${ }^{1}$, ANABELA C. CARUSO ${ }^{2}$, PAULO A. FARIA ${ }^{3}$, LICÍNIO E. DA SILVA ${ }^{4}$, \\ ELIENE C. DA FONSECA ${ }^{1}$, MAURO GELLER ${ }^{5}$, RODRIGO S. DE MOURA-NETO ${ }^{6}$ and VÂNIA S. LOPES ${ }^{1}$ \\ ${ }^{1}$ Hospital Universitário Antônio Pedro, Universidade Federal Fluminense, Programa de Pós-Graduação em Patologia, \\ Rua Marquês do Paraná, 303, 4º andar, sala 1, Centro, 24033-090 Niterói, RJ, Brasil \\ ${ }^{2}$ Instituto Nacional de Traumatologia e Ortopedia, Serviço de Anatomia Patológica, \\ Avenida Brasil, 500, Caju, 20940-070 Rio de Janeiro, RJ, Brasil \\ ${ }^{3}$ Instituto Nacional do Câncer, Divisão de Patologia, \\ Rua Cordeiro da Graça, 156, Santo Cristo, 20220-400 Rio de Janeiro, RJ, Brasil \\ ${ }^{4}$ Universidade Federal Fluminense, Departamento de Estatística do Instituto de Matemática e Estatística, \\ Rua Mario Santos Braga, s/n, $7^{\circ}$ andar, Centro, 24020-140 Niterói, RJ, Brasil \\ ${ }^{5}$ Centro Universitário Serra dos Órgãos/UNIFESO, Departamento de Microbiologia e Imunologia, \\ Av. Alberto Torres, 111, Alto, 25964-004 Teresópolis, RJ, Brasil \\ ${ }^{6}$ Universidade Federal do Rio de Janeiro, Instituto de Biologia, Av. Carlos Chagas Filho, Sala A1-050, Bloco A, \\ Edifício do Centro de Ciências da Saúde, Ilha do Fundão, 21941-902 Rio de Janeiro, RJ, Brasil
}

Manuscript received on December 11, 2012; accepted for publication on March 12, 2013

\begin{abstract}
AIMS: To study the expression of Bcl-2, Bcl-x, as well the presence of cleaved caspase-3 in neurofibromas and malignant peripheral nerve sheath tumors. The expression of Bcl-2 and Bcl-x and the presence of cleaved caspase 3 were compared to clinicopathological features of malignant peripheral nerve sheath tumors and their impact on survival rates were also investigated. MATERIALS AND METHODS: The evaluation of Bcl-2, Bcl-x and cleaved caspase-3 was performed by immunohistochemistry using tissue microarrays in 28 malignant peripheral nerve sheath tumors and 38 neurofibromas. Immunoquantification was performed by computerized digital image analysis. CONCLUSIONS: Apoptosis is altered in neurofibromas and mainly in malignant peripheral nerve sheath tumors. High levels of cleaved caspase- 3 are more common in tumors with more aggressive histological features and it is associated with lower disease free survival of patients with malignant peripheral nerve sheath tumors.
\end{abstract}

Key words: apoptosis regulatory proteins, malignant peripheral nervous sheath tumors, neurofibroma, Neurofibromatosis 1.

\section{INTRODUCTION}

Malignant peripheral nerve sheath tumors (MPNSTs) represent rare neoplasms, occurring in only $0.001 \%$ of general population (Ducatman et al. 1986). In individuals with Neurofibromatosis type 1

Correspondence to: Karin Soares Gonçalves Cunha

E-mail:karingcunha@gmail.com
(NF1), they occur in $4.6 \%$ of all cases, being this syndrome the major risk factor for the development of MPNSTs (Ducatman et al. 1986).

MPNSTs may appear de novo or may develop from the transformation of a benign neural neoplasm, mainly from a plexiform neurofibroma, which occurs almost exclusively in NF1 (Scheithauer et al. 1999). 
Nevertheless, the molecular events involved in the development of neurofibromas and MPNSTs are still not completely understood. Abnormal programmed cell death is a hallmark of human tumors and apoptosis resistance is one of the most marking features of the majority of malignant neoplasms (Bray et al. 2009). Among the many known regulators and effectors of apoptosis, the family of caspases plays an important role in the execution phases of this type of cell death. Caspase- 3 is considered to be the central protein in the execution of apoptosis and the detection of its activated form (cleaved caspase-3; CC3) is a valuable tool to detect apoptotic cells, even before the morphological features of apoptosis are present (Arai et al. 2005). Many proteins participate in the regulation of apoptosis; between them, there are the Bcl-2 family proteins, which include proapoptotic, e.g. Bax protein, and anti-apoptotic proteins, e.g. $\mathrm{Bcl}-2$ and $\mathrm{Bcl}-\mathrm{x}_{\mathrm{L}}$.

The altered expression of $\mathrm{Bcl}-2$ proteins family members and $\mathrm{CC} 3$ has been analysed in various benign and malignant neoplasms and their prognostic value has been demonstrated (Arai et al. 2005, Friess et al. 1998, Satoh et al. 2000, Biroccio et al. 2001). Nevertheless, few studies were performed with neurofibromas and MPNSTs and, to our knowledge, there is no study that investigated the presence of Bcl-2, Bcl-x and CC3 in these tumors and their the correlation to the clinicopathological features of MPNSTs and their impact on survival rates.

Studies that investigated the Bcl-2 expression in MPNSTs present different results, showing that there is still a lack of understanding of the involvement of this protein in their pathogenesis (Suster et al. 1998, Hirakawa et al. 1996, Miettinen et al. 1998, Dan'ura et al. 2002, Thanakit et al. 2006, Köhler et al. 2002). These divergent results may be a consequence of the small number of cases included in many investigations and also of the fact that most studies investigated MPNSTs together with other sarcomas, probably reflecting the difficulty of conducting research with larger number of cases of MPNSTs due to its rarity. Soft tissue sarcomas represent a heterogeneous group of tumors with different clinical behaviors. Therefore, a question raised about the studies evaluating prognostic factors in various histological types of sarcomas taken together, is that although the findings may be applicable to many sarcomas, certainly they not apply to all types sarcomas. Another important factor is that all previous studies used conventional pathologist-based manual scoring to quantify Bcl2-staining, which increases inter-observer and intraobserver variability.

The aim of this research was to study the expression of Bcl-2, Bcl-x, as well the presence of CC3 in MPNSTs and neurofibromas. The expression of $\mathrm{Bcl}-2$ and $\mathrm{Bcl}-\mathrm{x}$ and the presence of $\mathrm{CC} 3$ were compared to clinicopathological features of MPNSTs and their impact on survival rates were also investigated.

\section{MATERIALS AND METHODS}

Ethical Committee of National Institute of Cancer (INCA), RJ, Brazil, approved this study.

SAMPLE

The study sample comprises 16 cases of plexiform neurofibromas, 22 cases of non-plexiform neurofibromas (from NF1-patients and from non-NF1 patients), and 28 cases of MPNSTs, which were obtained from the pathology files of INCA and Hospital Universitário Antônio Pedro of the Universidade Federal Fluminense. All the cases were used in previous studies (Cunha et al. 2003, 2008, 2009). The samples of the tumors were included in two tissue microarray (TMA) paraffin blocks. For detailed information about the construction method for TMA block, please refer to the previous published paper (Cunha et al. 2012)

All the cases were reviewed by two pathologists. For neurofibromas, only cases with heterogeneous and diffuse immunostaining for S-100 protein were included. The samples of MPNSTs included in this study were obtained from the paraffin blocks of 
the resected primary tumor (in cases submitted to radiotherapy and/or chemotherapy prior to primary tumor resection, the biopsy material was used, since it had the same histological grade of the resection material). MPNSTs with one of the following features were included: arose within a peripheral nerve; arose in transition from a benign neural tumor; developed in a NF1 patient and exhibited the same histological features of most MPNSTs originating from a nerve; and developed in a non-NF1 patient, exhibited the same histological features as most MPNSTs and expressed S-100 protein (Dako Corp., Carpinteria, CA, USA, 1:4,000) and/or CD57 (clone TB01; Dako, 1:50). All samples were immunoreactive for anti-vimentin (clone V9; Dako, 1:800) and negative for anti-cytokeratin (clone AE1/ AE3; Dako, 1:400), anti-melanosome, (clone HMB-45, 1:200), anti-actin (smooth muscle; clone 1A4; Dako, 1:250), antiactin/muscle (clone HHF35; Dako, 1:1,000), and anti-desmin (clone D33; Dako, 1:100) antibodies, except the malignant Triton tumors, which exhibited anti-actin/muscle and desmin immunopositive areas.

Clinical and Pathological Features of MPNSTs INCLUDED IN THE STUDY

Tables I and II show the clinical and pathological features of MPNSTs included in this research, respectively. MPNSTs were classified in low and high-grade
(Scheithauer et al. 1999). Tumors were classified as low-grade if they presented mild to moderate cellularity, mild nuclear atypia, absence of necrosis and no or few mitoses (mitotic index $<4$ ). Tumors were classified as high-grade if they had marked cellularity, variable cellular pleomorphism and easily identified mitoses (mitotic index $\geq 4$ ). Mitotic index was calculated by the sum of mitotic figures in 10 high-power fields. In each case, at least 30 fields were analyzed and the mean value of the sum of mitotic figures in each 10 high-power fields was obtained.

Epithelioid MPNSTs included in this study were composed predominantly of epithelioid cells and presented spindle cells identical to that of conventional MPNSTs. Malignant triton tumors had areas of cells with rabdomyoblast morphology, which expressed desmin and/or actin/muscle.

\section{IMMUNOHISTOCHEMICAL STAINING}

Sections with $3 \mu \mathrm{m}$ from the two TMA paraffin blocks were cut and collected on silane-coated slides. After dewaxing, proteins were demonstrated by IHC, using the protocol described in a previous study (Cunha et al. 2009). Sections were incubated overnight at $4^{\circ} \mathrm{C}$ with a 1:200 dilution of the primary antibody anti-Bcl-2 (clone 124; Dako Corporation, USA), with a 1:25 dilution of the primary antibody anti-Bcl-x (clone A3510; Dako Corporation, USA), and with a 1:600 dilution

TABLE I

Clinical data of patients with malignant peripheral nerve sheath tumors.

\begin{tabular}{|c|c|c|c|c|c|c|c|c|c|c|c|c|c|}
\hline ت & 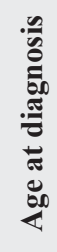 & $\ddot{\ddot{D}}$ & ॄ̈ & $\overline{\mathbf{z}}$ & $\stackrel{\mathscr{N}}{\circ}$ & 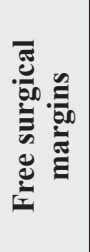 & & 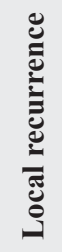 & 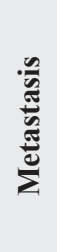 & 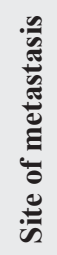 & 忢 & 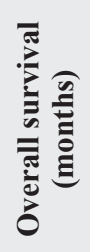 & 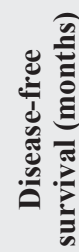 \\
\hline 1 & 27 & $\mathrm{~F}$ & - & Yes & Lumbar & No & Resection & Yes & No & & No & 21.60 & 18.23 \\
\hline 2 & 44 & $\mathrm{~F}$ & $\mathrm{~W}$ & No & Left elbow & No & Resection + Rxt & No & $\mathrm{No}$ & & No & 13.60 & 13.60 \\
\hline 3 & 29 & $\mathrm{~F}$ & - & Yes & Right flank & No & Resection + Rxt & No & No & & Yes & 12.47 & 12.47 \\
\hline 4 & 23 & $\mathrm{~F}$ & $\mathrm{~B}$ & Yes & Pelvis & No & Resection & No & No & & Yes & 4.87 & 4.87 \\
\hline
\end{tabular}

—, information not avaiable; F, female; M, male; B, black; W, white; Rxt, radiotherapy; Ct, chemotherapy;

* these patients presented metastasis at the moment of the tumor diagnosis. 
TABLE I (continuation)

\begin{tabular}{|c|c|c|c|c|c|c|c|c|c|c|c|c|c|}
\hline 苑 & 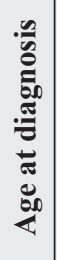 & ¿্் & 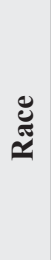 & $\overline{\mathbf{Z}}$ & 范 & 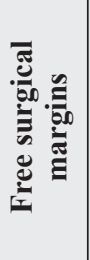 & & 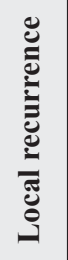 & 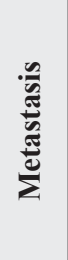 & 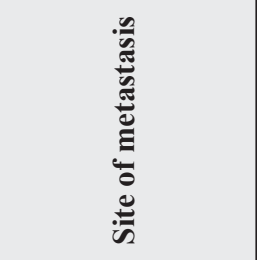 & 胥 & 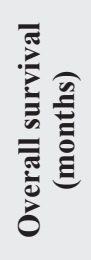 & 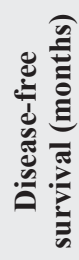 \\
\hline 5 & 28 & $\mathrm{~F}$ & $\mathrm{~W}$ & Yes & Right flank & Yes & Resection & No & No & & No & 76.13 & 76.13 \\
\hline 6 & 32 & $\mathrm{~F}$ & $\mathrm{~W}$ & No & Left lower limb & Yes & Resection & No & Yes & Lung & No & 12.10 & $.00 *$ \\
\hline 7 & 34 & $\mathrm{~F}$ & $\mathrm{~W}$ & No & Right lower limb & Yes & Resection & No & No & & No & 44.77 & 44.77 \\
\hline 8 & 40 & $\mathrm{~F}$ & $\mathrm{~W}$ & No & Breast & No & Resection + Rxt & No & No & & No & 96.90 & 96.90 \\
\hline 9 & 20 & $\mathrm{~F}$ & - & Yes & Lumbar & - & Rxt & No & No & & Yes & 1.83 & 1.83 \\
\hline 10 & 53 & $\mathrm{~F}$ & $\mathrm{~B}$ & Yes & Left shoulder & Yes & Resection & No & No & & Yes & 10.87 & 10.87 \\
\hline 11 & 21 & $\mathrm{~F}$ & W & Yes & Left lower limb & Yes & Resection & No & No & & No & 67.50 & 67.50 \\
\hline 12 & 23 & M & W & Yes & Left lower limb & - & $\mathrm{Ct}$ & No & Yes & Lung & Yes & 2.73 & $.00 *$ \\
\hline 13 & 42 & $\mathrm{~F}$ & $\mathrm{~W}$ & No & Pelvis & No & Resection $+\mathrm{Rxt}$ & No & Yes & Liver and pancreas & Yes & 11.30 & 9.60 \\
\hline 14 & 68 & M & $\mathrm{W}$ & No & Right upper limb & - & Resection + Rxt & Yes & No & & No & 9.50 & 7.00 \\
\hline 15 & 19 & M & $\mathrm{W}$ & No & Right upper limb & - & Rxt & No & Yes & Lung & No & 16.10 & $.00 *$ \\
\hline 16 & 23 & $\mathrm{~F}$ & $\mathrm{~W}$ & Yes & Sacrum and spine & - & Rxt & No & Yes & Lung & Yes & 7.73 & 7.67 \\
\hline 17 & 34 & $\mathrm{~F}$ & $\mathrm{~B}$ & Yes & Abdomen & No & Resection & Yes & No & & No & 10.10 & 5.43 \\
\hline 18 & 60 & $\mathrm{~F}$ & $\mathrm{~B}$ & Yes & Right lower limb & Yes & Resection & No & Yes & Lung & No & 40.80 & 22.83 \\
\hline 19 & 40 & $\mathrm{~F}$ & $\mathrm{~B}$ & No & Thorax & Yes & Resection + Rxt & No & No & & No & 61.10 & 61.10 \\
\hline 20 & 78 & $\mathrm{~F}$ & W & No & Face sinus & No & Resection + Rxt & Yes & No & & Yes & 77.90 & 50.20 \\
\hline 21 & 24 & M & W & Yes & Right upper limb & - & Biopsy $+\mathrm{Ct}$ & No & Yes & Lung & Yes & 12.80 & 6.60 \\
\hline 22 & 45 & M & $\mathrm{B}$ & Yes & Abdomen & - & Resection & Yes & Yes & Lung & Yes & 14.70 & 13.07 \\
\hline 23 & 63 & M & $\mathrm{B}$ & Yes & Supraclavicular & Yes & Resection & No & No & & Yes & 60.30 & 60.30 \\
\hline 24 & 85 & $\mathrm{M}$ & $\mathrm{W}$ & No & Head (temporal) & Yes & Resection & No & No & & Yes & 20.20 & 20.20 \\
\hline 25 & 72 & $\mathrm{~F}$ & W & No & Left lower limb & Yes & Resection + Rxt & No & Yes & Lung & Yes & 42.00 & 39.93 \\
\hline 26 & 80 & $\mathrm{~F}$ & $\mathrm{~W}$ & No & Right foot & Yes & Resection & Yes & No & & Yes & 13.40 & 8.10 \\
\hline 27 & 30 & $\mathrm{~F}$ & $\mathrm{~B}$ & No & Thorax & Yes & Resection + Rxt & No & Yes & Bone & No & 35.70 & 4.67 \\
\hline 28 & 41 & M & $\mathrm{B}$ & Yes & Right lower limb & - & Rxt & No & Yes & Cervical region & Yes & 7.20 & 6.97 \\
\hline
\end{tabular}

—, information not avaiable; F, female; $\mathbf{M}$, male; $\mathbf{B}$, black; W, white; Rxt, radiotherapy; $\mathbf{C t}$, chemotherapy;

* these patients presented metastasis at the moment of the tumor diagnosis. 
TABLE II

Pathological data of the malignant peripheral nerve sheath tumors.

\begin{tabular}{|c|c|c|c|c|c|}
\hline $\begin{array}{c}\text { Case } \\
\text { number }\end{array}$ & Size $(\mathbf{c m})$ & Grade & $\begin{array}{c}\text { Presence of heterologous } \\
\text { differentiation }\end{array}$ & Necrosis & $\begin{array}{c}\text { Mitotic index (mitotic figures } \\
\text { in } 10 \text { high-power fields)* }\end{array}$ \\
\hline 1 & 4.6 & high & no & no & $7.0(\mathrm{sd}=2.0)$ \\
\hline 2 & 17.0 & high & rabdomiosarcomatous areas & yes & $9.3(\mathrm{sd}=1.5)$ \\
\hline 3 & 15.0 & high & no & yes & $5.3(\mathrm{sd}=1.2)$ \\
\hline 4 & 21.0 & high & rabdomiosarcomatous areas & yes & $17.0(\mathrm{sd}=2.0)$ \\
\hline 5 & 7.0 & low & chondrosarcomatous areas & no & $3.7(\mathrm{sd}=1.5)$ \\
\hline 6 & 21.0 & high & no & yes & $7.0(\mathrm{sd}=3.5)$ \\
\hline 7 & 10.0 & high & no & no & $9.0(\mathrm{sd}=2.0)$ \\
\hline 8 & 16.0 & low & no & no & $0.3(\mathrm{sd}=0.6)$ \\
\hline 9 & - & high & no & no & $18.0(\mathrm{sd}=4.0)$ \\
\hline 10 & 28.0 & high & no & yes & $19.0(\mathrm{sd}=1.0)$ \\
\hline 11 & 17.0 & high & no & yes & $13.0(\mathrm{sd}=2.6)$ \\
\hline 12 & - & high & no & yes & $10.7(\mathrm{sd}=1.5)$ \\
\hline 13 & 13.0 & high & chondrosarcomatous areas & yes & $10.3(\mathrm{sd}=5.7)$ \\
\hline 14 & - & high & no & no & $10.3(\mathrm{sd}=4.0)$ \\
\hline 15 & - & low & epithelioid & no & $3.0(\mathrm{sd}=0.0)$ \\
\hline 16 & - & high & no & yes & $7.0(\mathrm{sd}=2.6)$ \\
\hline 17 & 13.0 & high & epithelioid & yes & $7.3(\mathrm{sd}=1.2)$ \\
\hline 18 & 12.0 & high & chondrosarcomatous area & no & $6.0(\mathrm{sd}=2.0)$ \\
\hline 19 & 6.0 & low & no & no & $2.3(\mathrm{sd}=1.5)$ \\
\hline 20 & - & low & no & no & $3.0(\mathrm{sd}=1.0)$ \\
\hline 21 & - & high & no & yes & $7.0(\mathrm{sd}=2.0)$ \\
\hline 22 & 23.0 & high & no & yes & $13.3(\mathrm{sd}=3.2)$ \\
\hline 23 & 5.0 & high & chondroma area & no & $7.0(\mathrm{sd}=2.0)$ \\
\hline 24 & 10.0 & low & no & no & $3.7(\mathrm{sd}=1.5)$ \\
\hline 25 & 13.0 & low & no & no & $3.7(\mathrm{sd}=1.2)$ \\
\hline 26 & 3.0 & high & no & no & $6.7(\mathrm{sd}=0.6)$ \\
\hline 27 & 11.0 & high & no & no & $13.0(\mathrm{sd}=3.0)$ \\
\hline 28 & - & high & no & yes & $8.0(\mathrm{sd}=1.0)$ \\
\hline
\end{tabular}

—, information not available (the tumor resection was performed in other institution); sd, standard deviation

*, in each case, at least 30 fields were analyzed and the mean value of the sum of mitotic figures in each 10 high-power fields is showed in the table.

of the primary antibody anti-CC3 (clone Asp175; Cell Signaling Technology, USA). Palatine tonsil was used as a positive control. The negative control was established by omission of primary antibody.
The glass slides were reviewed independently by two pathologists and were scored as negative or positive. The location (nucleus, cytoplasm and/ or cytoplasmic membrane) of immunopositivity 
for Bcl-2, Bcl-x and CC3 was also evaluated. Following the independent evaluation of the immunohistochemical staining, if there were any divergence between the pathologists, the glass slides were discussed at a separate evaluation in order to reach a consensus on the evaluation. For the cases classified as positive, quantification of Bcl2, Bcl-x and $\mathrm{CC} 3$ immunostaining was performed by computerized digital image analysis (ImagePro Plus software v4.5; Media Cybernetics), as previously described (Cunha et al. 2009), and expressed as positivity index (PI), defined as positive area divided by total tissue area.

To avoid searching the optimal cut-off point for the immunostaining to perform the statistical analyzes (overall and disease-free survivals), which could be misleading and associated with difficulty in its interpretation, we arranged the cases of MPNSTs in ascending order according to PI values and divided them into two groups: one with tumors with high PI (cases in the third third of the list) and another with tumors with low PI (cases in first two-thirds of the list).

\section{STATISTICAL ANALYSIS}

Clinicopathological and immunohistochemical variables were compared by Chi-square, Fisher's exact, Student t, and Mann-Whitney tests. The Kaplan-Meier method was used to evaluate survival curves and statistical significance of clinicopathological variables was determined by log-rank test. Multivariate analysis was performed by Cox-regression model. SPSS software v.11 was used for statistical analysis. Differences were considered significant if $\mathrm{p}<0.05$.

\section{RESULTS}

Data regarding the immunostaining for $\mathrm{Bcl}-2$, $\mathrm{Bcl}-\mathrm{x}$ and $\mathrm{CC} 3$ in neurofibromas and MPNSTs are described in Table III.

TABLE III

Immunohistochemical data of neurofibromas and of malignant peripheral nerve sheath tumors.

\begin{tabular}{|c|c|c|c|c|c|c|c|}
\hline \multicolumn{8}{|c|}{ Neurofibromas } \\
\hline Antibody & Group & $\begin{array}{l}\% \text { positive } \\
\text { cases }(n)\end{array}$ & $\begin{array}{c}\text { Mean } \\
\text { of PI }\end{array}$ & $\begin{array}{l}\text { Standard } \\
\text { Deviation }\end{array}$ & $\begin{array}{c}\text { Mean } \\
\text { of PI }\end{array}$ & IP $\min / \max$ & $\begin{array}{c}\text { IQ } \\
\text { Range }\end{array}$ \\
\hline \multirow{3}{*}{ Anti-Bcl-2 } & Neurofibromas & & & & & & \\
\hline & Plexiform neurofibromas & $18.8 \%(n=3)$ & 0.0299 & 0.0266 & 0.0285 & $0.0000 / 0.0571$ & - \\
\hline & Non-plexiform neurofibromas & $42.9 \%(n=9)$ & 0.0789 & 0.1081 & 0.0355 & $0.0000 / 0.3583$ & 0.0570 \\
\hline \multirow{3}{*}{ Anti-Bcl-x } & Neurofibromas & $43.2 \%(n=16)$ & 0.0043 & 0.0055 & 0.0019 & $0.0000 / 0.0171$ & 0.0091 \\
\hline & Plexiform neurofibromas & $37.5 \%(n=6)$ & 0.0046 & 0.0050 & 0.0044 & $0.0000 / 0.0094$ & 0.0092 \\
\hline & Non-plexiform neurofibromas & $47.6 \%(n=10)$ & 0.0041 & 0.0061 & 0.0019 & $0.0000 / 0.0171$ & 0.0064 \\
\hline \multirow{3}{*}{ Anti-CC3 } & Neurofibromas & $100 \%(n=28)$ & 0.0044 & 0.0486 & 0.0275 & $0.0000 / 0.0240$ & 0.0545 \\
\hline & Plexiform neurofibromas & $100 \%(n=28)$ & 0.0347 & 0.0038 & 0.0025 & $0.0000 / 0.0130$ & 0.0036 \\
\hline & Non-plexiform neurofibromas & $100 \%(n=28)$ & 0.0050 & 0.0055 & 0.0027 & $0.0004 / 0.0240$ & 0.0070 \\
\hline \multicolumn{8}{|c|}{ Malignant Peripheral Nerve Sheath Tumors (MPNSTs) } \\
\hline Antibody & Group & $\begin{array}{c}\% \text { of positive } \\
\text { cases (n) }\end{array}$ & $\begin{array}{l}\text { Mean } \\
\text { of PI }\end{array}$ & $\begin{array}{l}\text { Standard } \\
\text { Deviation }\end{array}$ & $\begin{array}{c}\text { Mean } \\
\text { of PI }\end{array}$ & IP $\min / \max$ & $\begin{array}{c}\text { IQ } \\
\text { Range }\end{array}$ \\
\hline Anti-Bcl-2 & MPNST & $78,6 \%(n=22)$ & 0.4684 & 0.0543 & 0.2500 & $0.0000 / 0.2176$ & 0.0724 \\
\hline Anti-Bcl-x & MPNST & $75 . \%(n=21)$ & 0.0347 & 0.0526 & 0.0054 & $0.0000 / 0.2036$ & 0.0533 \\
\hline Anti-CC3 & MPNST & $100.0 \%(n=28)$ & 0.1672 & 0.1352 & 0.0990 & $0.0324 / 0.5346$ & 0.1900 \\
\hline
\end{tabular}

CC3, cleaved caspase 3; PI, positive index; min, minimum; max, maximum; IQ, interquartile. 
CEllular LOCATION OF IMMUNOSTAINING FOR BCL-2, BCL-X AND CLEAVED CASPASE-3

Immunostaining for proteins $\mathrm{Bcl}-2$ and $\mathrm{Bcl}-\mathrm{x}$ was found in the cytoplasm of tumor cells of neurofibromas and MPNSTs (Fig. 1). Moreover, expression of Bcl-2 and Bcl-x was also observed in the endothelial cells of blood vessels, as well as in lymphocytes, when present in the tumor. Regarding the presence of $\mathrm{CC} 3$, neurofibromas showed only nuclear immunostaining (Fig. 2A). In contrast, half of MPNSTs showed only nuclear immunostaining and the other $50 \%$ of the cases showed cytoplasmic and nuclear staining (Fig. 2B, 2C and 2D).
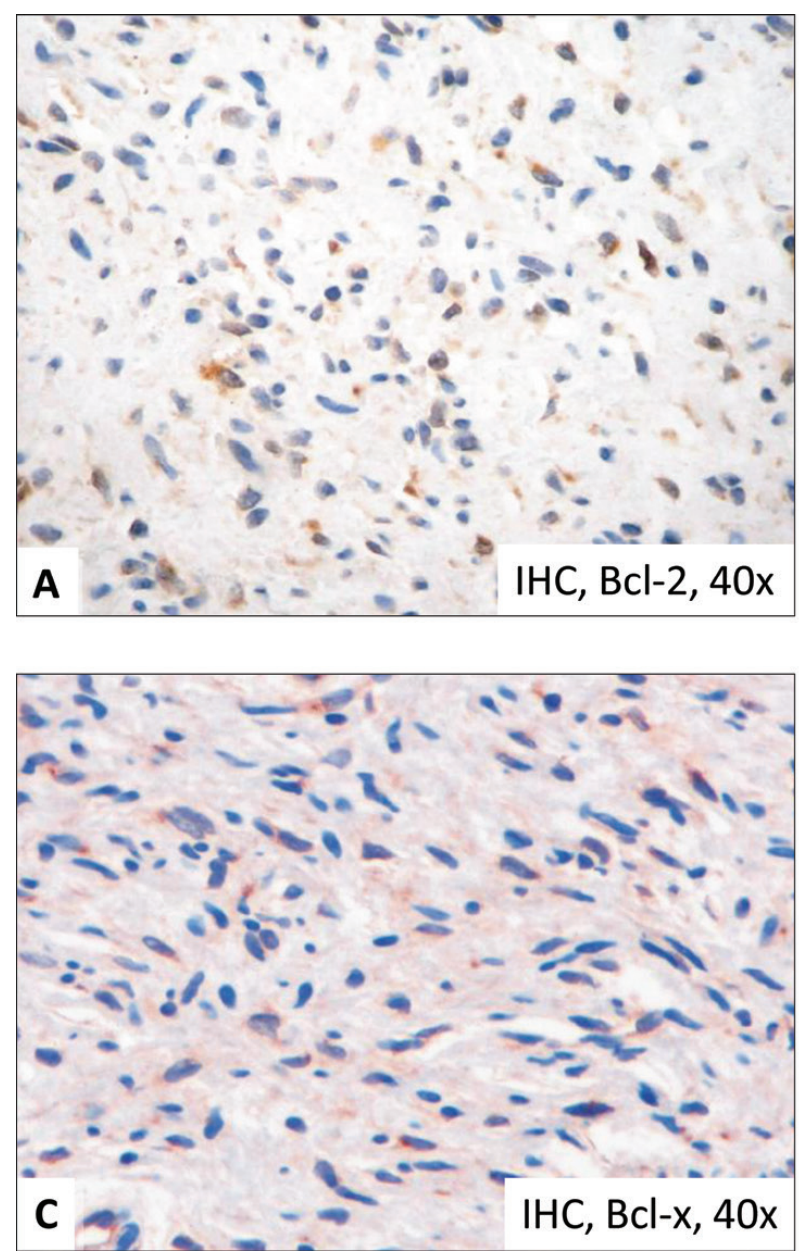

COMPARISON OF IMMUNOSTAINING FOR BCL-2, BCL-X AND Cleaved CASPase-3 BetweEn the Different TyPes of NEUROFIBROMAS

There was no statistically significant difference between plexiform neurofibromas and nonplexiform neurofibromas regarding the percentage of tumors that expressed Bcl-2 (Fisher's exact test, $\mathrm{p}=0.166$ ) and Bcl-x (Chi-square test; $\mathrm{p}=0.539$ ) proteins. With respect to $\mathrm{CC} 3$, all neurofibromas were immunopositive, expressing the protein only in the nucleus.

Considering the immunopositive cases for each antibody, there was no statistically significant difference of PIs between the two groups of
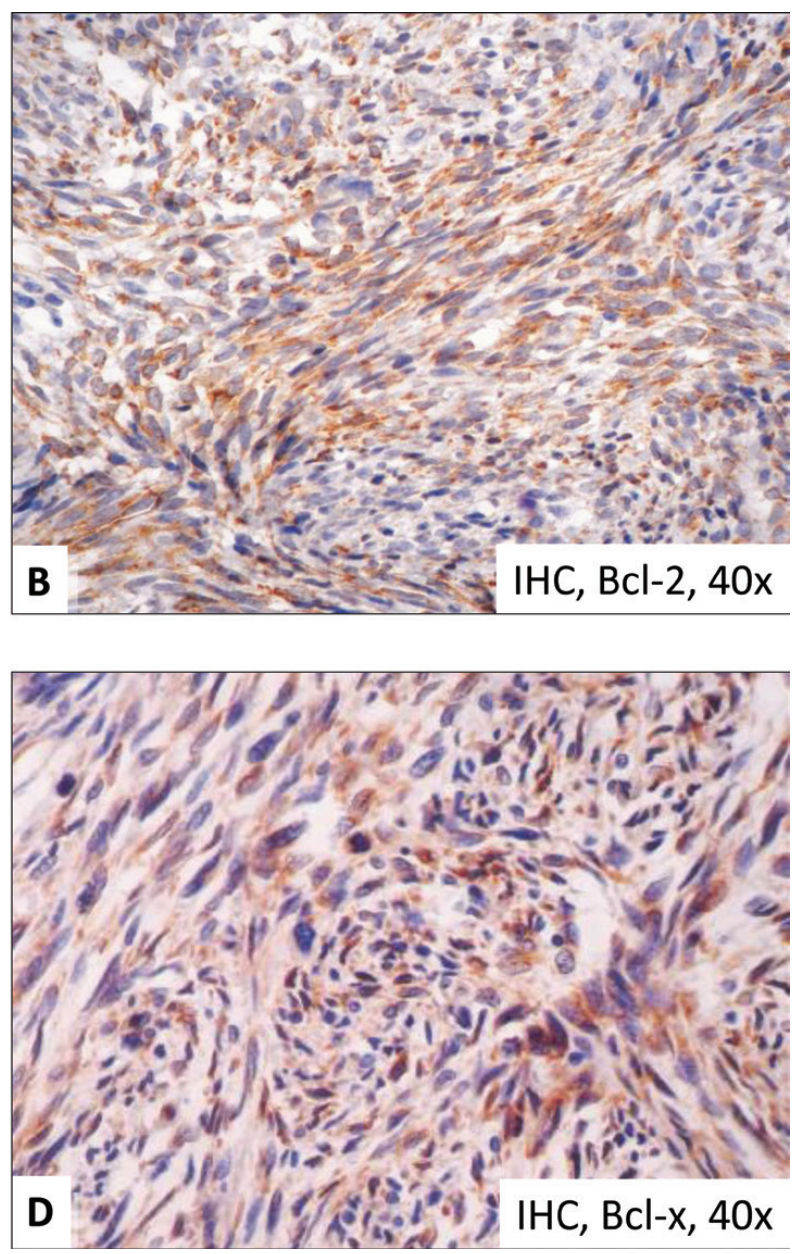

Fig. 1 - A. Neurofibroma showing cytoplasmic immunostaining for Bcl-2; B. MPNST with cytoplasmic immunostaining for Bcl-2; C. Neurofibroma showing cytoplasmic immunostaining for Bcl-x; D. MPNST with cytoplasmic immunostaining for Bcl-x. 

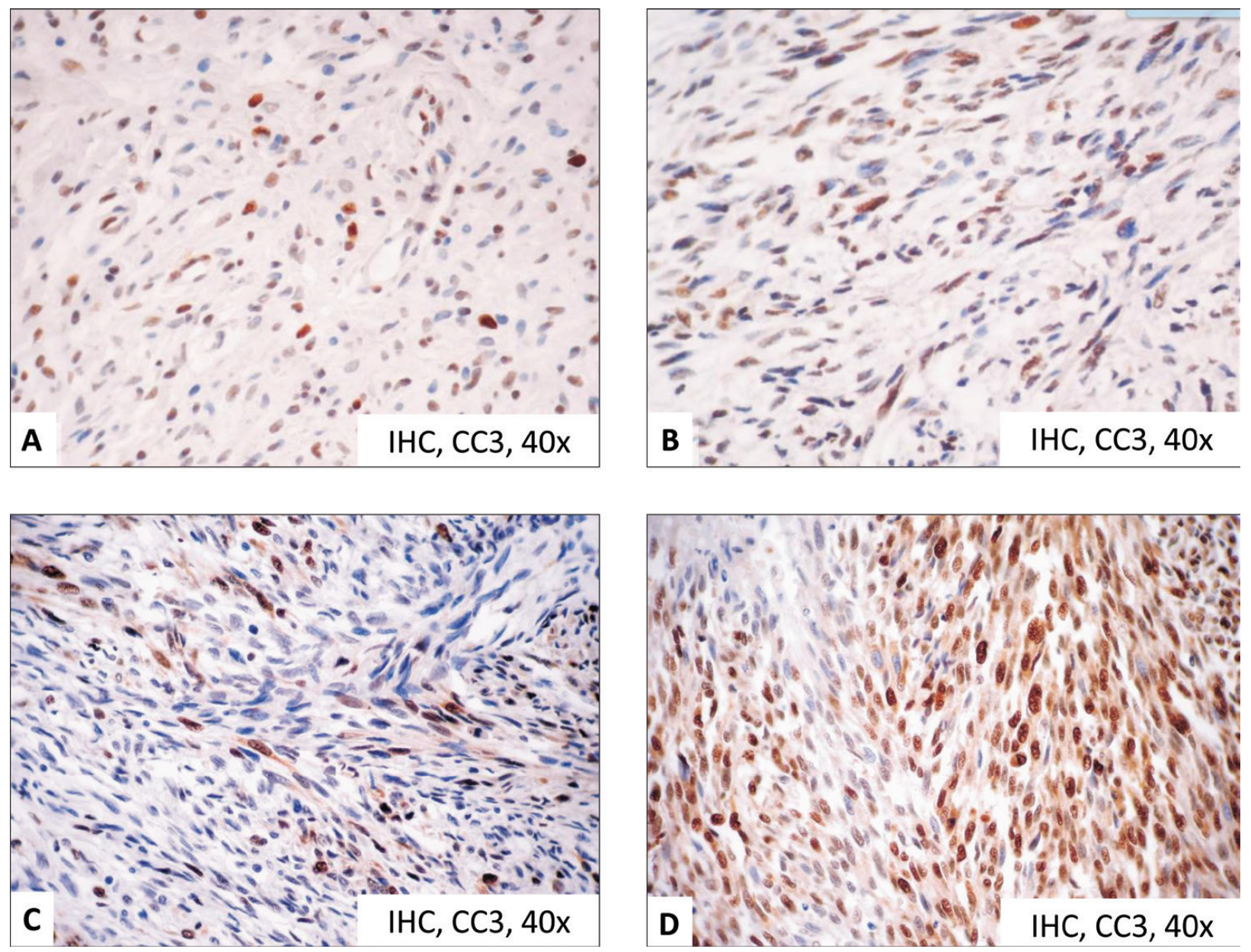

Fig. 2 - A. Neurofibroma showing nuclear immunostaining for CC3. B. MPNST showing nuclear immunostaining for CC3. C and D. MPNST showing nuclear and cytoplasmic immunostaining for CC3.

neurofibromas: Bcl-2 (Mann-Whitney test, $\mathrm{p}=0.373$ ), Bcl-x (Mann-Whitney test, $\mathrm{p}=0.562$ ) and CC3 (MannWhitney test, $\mathrm{p}=0.554)$.

COMPARISON OF IMMUNOSTAINING FOR BCL-2, BCL-X AND Cleaved Caspase-3 Between Malignant Peripheral

Nerve Sheath Tumors AND NEUROFIBromas

There were more positive MPNSTs for Bcl-2 (Chisquare test, $\mathrm{p}<0.001$ ) and Bcl-x (Chi-square test; $\mathrm{p}$ $<0.0001)$ than neurofibromas. Bcl-2 PI in positive neurofibromas did not differ statistically from the PI of positive MPNSTs (Mann-Whitney test, $\mathrm{p}=0.989$ ). In contrast, positive MPNSTs showed higher Bcl-x PI than positive neurofibromas (Mann-Whitney test, $\mathrm{p}=0.002$ ). All neurofibromas and MPNSTs expressed CC3. Nevertheless, MPNSTs showed higher CC3 PI than neurofibromas (Mann-Whitney test, $\mathrm{p}<0.001$ ).

COMPARISON OF IMMUNOSTAINING FOR BCL-2, BCL-X AND CC3 With CLINICOPATHOLOGICAL FEATURES OF CASES OF MALIGNANT PERIPHERAL NERVE SHEATH TUMORS

We investigated the correlation of the immunostaining of $\mathrm{Bcl}-2, \mathrm{Bcl}-\mathrm{x}$ and $\mathrm{CC} 3$ with the presence of NF1, recurrence and metastasis, histological grade, mitotic index and necrosis. In all tests performed, presence of NF1 (Fisher's exact test, $\mathrm{p}=0.011$ ), high histological grade (Fisher's exact test, $\mathrm{p}=0.003$ ) and high mitotic index (Fisher's 
exact test, 0.006) were correlated to the presence of $\mathrm{CC} 3$ in the cytoplasm of MPNSTs cells. There was also statistically significant correlation between high CC3 PI in MPNSTs with high histological grade (Mann-Whitney test, $\mathrm{p}=0.012$ ), high mitotic index (Mann-Whitney test, $\mathrm{p}=0.037$ ) and necrosis (Mann-Whitney test, $\mathrm{p}=0.010$ )

Overall and Disease Free Survival and Prognostic

Factors in Cases of Malignant Peripheral Nerve

SHEATH TUMORS

The overall 5-year survival rate of patients with MPNST was $46 \%$. Considering the patients who received curative treatment, the 5-year diseasefree survival rate was $39 \%$. All these data were showed in the previous study in which we used the same sample (Cunha et al. 2012). In that study, we evaluated the influence of clinical and pathological features on overall and disease free survival in patients with MPNSTs: sex, presence of NF1, tumor location, treatment performed, status of the surgical margins, local recurrence, metastasis, histological grade, mitotic index, necrosis, epithelioid variant, Triton tumor and chondrosarcoma differentiation. The variables, which were significant in univariate log-rank analysis for survival rates, are shown in Table $\mathrm{IV}$, as well as the results of the evaluation of Bcl2, Bcl-x and CC3. Presence of NF1 ( $p=0.044)$, high histological grade $(\mathrm{p}=0.045)$, presence of necrosis $(p=0.003)$ and high CC3 PI $(p=0.024)$ were significant in univariate log-rank analysis for shorter overall survival and were included in Cox regression model, which showed that the presence of necrosis was an independent prognosis factor for lower overall survival $(p=0.007)$. (Table V) Epithelioid variant $(p=0.036)$ and high CC3 PI $(p<0.001)$ were significant in univariate log-rank analysis for disease-free survival (Table II). Cox regression model showed that high CC3 PI could be considered an independent prognosis factor for disease-free survival $(p=0.002)$ (Table V).

\section{DISCUSSION}

To our knowledge, the present study was the first to use computerized image analysis to calculate the Bcl-2 expression in neurofibromas and MPNSTs. The results showed a significantly higher percentage of positive MPNSTs for Bcl-2 than neurofibromas $(p<0.001)$. Other studies also observed increased expression of Bcl-2 in malignant neoplasms, such as cutaneous carcinomas and melanomas, when compared to their benign counterparts, suggesting that the expression of $\mathrm{Bcl}-2$ protein could be an oncogenic factor (Leiter et al. 2000, Hussein et al. 2004). Corroborating to our findings, other studies also observed that most MPNSTs express Bcl-2 (Miettinen et al. 1998, Watanabe et al. 2001, Sabah et al. 2007). Contrary to our results, Suster et al. (1998) found that $87.5 \%$ of eight neurofibromas expressed Bcl-2, while only $39.3 \%$ of 25 MPNSTs were immunoreactive. In another survey with 38 sarcomas, none of the four studied MPNSTs expressed the Bcl-2 protein. In two studies that included MPNSTs, which arose from neurofibromas (one study with eight and the other with 20 cases), there was no difference in $\mathrm{Bcl}-2$ expression between the benign and malignant counterparts (Thanakit et al. 2006, Watanabe et al. 2001).

Bcl-2 expression has been correlated with histological grade and clinical behavior of several malignant neoplasms (Hirakawa et al. 1996, Sabah et al. 2007, Silvestrini et al. 1994, Ofner et al. 1995, Groeger et al. 2004). In certain cancers, like breast carcinomas, the expression of this protein is more commonly observed in lowgrade neoplasms, whereas in other tumors, such as bladder carcinoma and some sarcomas, its expression has been more common in high-grade tumors (Sabah et al. 2007, Yang et al. 2000, Eissa and Seada 1998). It has been demonstrated that the immunoreactivity to the $\mathrm{Bcl}-2$ is associated with increased survival in patients with colorectal, breast, lung and ovary carcinomas (Silvestrini et 
KARIN S. CUNHA ET AL.

TABLE IV

Results of the influence of variables on overall and disease-free survival in patients with malignant peripheral nerve sheath tumors.

\begin{tabular}{|c|c|c|c|c|}
\hline Variables & $\begin{array}{l}\text { Total SV } \\
\text { (months) }\end{array}$ & $\begin{array}{l}\text { Total SV (p log- } \\
\text { rank) }\end{array}$ & $\begin{array}{c}\text { Disease-free } S V \\
\text { (months) }\end{array}$ & $\begin{array}{c}\text { Disease-free } S V \\
(p \log \text {-rank })\end{array}$ \\
\hline \multicolumn{5}{|l|}{ NF1 } \\
\hline Yes & 31.6 & $\underline{0.044}$ & 31.4 & 0.959 \\
\hline No & 59.9 & & 41.6 & \\
\hline \multicolumn{5}{|l|}{ Histological Grade } \\
\hline High & 31.7 & $\underline{0.045}$ & 23.94 & 0.095 \\
\hline Low & 68.6 & & 65.28 & \\
\hline \multicolumn{5}{|l|}{ Necrosis } \\
\hline Yes & 19.1 & $\underline{0.003}$ & 23.95 & 0.138 \\
\hline No & 62.4 & & 50.23 & \\
\hline \multicolumn{5}{|l|}{ Epithelioid Variant } \\
\hline Yes & $*$ & $*$ & 6.21 & $\underline{0.036}$ \\
\hline No & 44.49 & & 43.98 & \\
\hline \multicolumn{5}{|l|}{ Bcl-2 protein expression } \\
\hline Positive & 43.2 & 0.922 & 26.1 & 0.679 \\
\hline Negative & 46.1 & & 47.4 & \\
\hline Low PI & 50.0 & 0.811 & 42.5 & 0.867 \\
\hline High PI & 34.3 & & 36.0 & \\
\hline \multicolumn{5}{|l|}{ Bcl-x protein expression } \\
\hline Positive & 46.7 & 0.916 & 29.5 & 0.579 \\
\hline Negative & 47.2 & & 49.2 & \\
\hline Low PI & 46.9 & 0.803 & 54.7 & 0.312 \\
\hline High PI & 41.0 & & 27.3 & \\
\hline \multicolumn{5}{|l|}{ CC3 protein expression } \\
\hline Nuclear & 54.2 & & 42.5 & \\
\hline Nuclear and cytoplasmic & 37.6 & 0.301 & 36.0 & 0.867 \\
\hline Low PI & 55.3 & & 56.8 & \\
\hline High PI & 14.6 & $\underline{0.024}$ & 6,9 & $\leq 0.00$ \\
\hline
\end{tabular}

SV, survival; PI, positive index; *, the value could not be calculated because all cases were censored.

al. 1994, Ofner et al. 1995, Yoo et al. 2007, Nadler et al. 2008, Yang et al. 2000). Conversely, in other tumors, such as non-small-cell lung carcinomas, the expression of this protein has been correlated with poor survival (Groeger et al. 2004). Our results showed no correlation between the expression of Bcl-2 and histological grade, as well as no correlation between the expression of Bcl-2 and survival of patients with MPNSTs, similarly to other studies with different tumors. (Hirakawa et al. 1996, Paik et al. 2006, Tsutsui et al. 2006).

$\mathrm{Bcl}-\mathrm{x}$ is another member of the $\mathrm{Bcl}-2$ proteins family that has been extensively studied in many tumors. Two isoforms, $\mathrm{Bcl}-\mathrm{x}_{\mathrm{S}}$ and $\mathrm{Bcl}-\mathrm{x}_{\mathrm{L}}$, can be generated by alternative splicing of $\mathrm{Bcl}-\mathrm{x}$ transcripts, having an inductor and inhibition function on apoptosis, respectively (Schoelch et al. 1999). In some malignant neoplasms, higher expression of 
TABLE V

Results of the Cox regression model for significant variables in univariate analysis for overall and disease free survival.

\begin{tabular}{|c|c|c|c|c|c|}
\hline \multirow{2}{*}{\multicolumn{2}{|c|}{ Co-variables }} & \multirow{2}{*}{ p-value } & \multirow{2}{*}{$\operatorname{Exp}(B)$} & \multicolumn{2}{|c|}{$95,0 \%$ CI for $\operatorname{Exp}(B)$} \\
\hline & & & & Lower & Upper \\
\hline \multicolumn{6}{|c|}{ Overall Survival } \\
\hline \multirow{5}{*}{ Step 1} & Neurofibromatosis type 1 & 0.448 & 0.591 & 0.152 & 2.301 \\
\hline & Histological Grade & 0.831 & 1.248 & 0.164 & 9.529 \\
\hline & Necrosis & 0.343 & 0.468 & 0.097 & 2.250 \\
\hline & High PI of CC3 & 0.469 & 1.657 & 0.423 & 6.497 \\
\hline & Mitotic Index & 0.525 & 1.054 & 0.895 & 1.242 \\
\hline \multirow{4}{*}{ Step 2} & Presence of NF1 & 0.417 & 0.573 & 0.149 & 2.196 \\
\hline & Necrosis & 0.318 & 0.451 & 0.095 & 2.152 \\
\hline & High PI of CC3 & 0.472 & 1.655 & 0.419 & 6.543 \\
\hline & Mitotic Index & 0.438 & 1.062 & 0.913 & 1.235 \\
\hline \multirow{3}{*}{ Step 3} & Presence of NF1 & 0.465 & 0.609 & 0.161 & 2.301 \\
\hline & Necrosis & 0.255 & 0.413 & 0.090 & 1.897 \\
\hline & Mitotic Index & 0.289 & 1.083 & 0.935 & 1.254 \\
\hline \multirow{2}{*}{ Step 4} & Necrosis & 0.143 & 0.343 & 0.082 & 1.434 \\
\hline & & 0.226 & 1.093 & 0.947 & 1.261 \\
\hline Step 5 & Necrosis & 0.007 & 0.199 & 0.062 & 0.639 \\
\hline \multicolumn{6}{|c|}{ Disease Free Survival } \\
\hline \multirow[t]{2}{*}{ Step 1} & Epithelioid variant & 0.705 & 0.801 & 0.254 & 2.528 \\
\hline & High PI of CC3 & 0.001 & 7.727 & 2.194 & 27.208 \\
\hline Step 2 & High PI of CC3 & 0.002 & 7.707 & 2.183 & 27.210 \\
\hline
\end{tabular}

$\mathrm{CI}=$ confidence interval.

anti-apoptotic Bcl- $\mathrm{x}_{\mathrm{L}}$ protein was observed, when compared to corresponding normal tissues (Leiter et al. 2000, Guo et al. 2002). In a study with an established NF1-associated MPNST cell line and primary tissue cultured MPNST cells derived from a NF1 patient, high expression of Bcl- $\mathrm{x}_{\mathrm{L}}$ was observed (Lee et al. 2012). In another recent study with cell lines, it was found that $\mathrm{Bcl}-\mathrm{x}_{\mathrm{L}}$ is upregulated in Schwann cells derived from NF1-associated MPNST compared to neurofibromas from NF1 patients and was suggested that this upregulation may be caused by NF1 deficiency-mediated elevation in Ras signaling. (Park et al. 2013)

Our results showed that there was a higher number of positive MPNSTs for Bcl-x than neurofibromas ( $\mathrm{p}<0.001)$. Moreover, positive
MPNSTs had higher PIs than neurofibromas $(p=0.002)$. Interestingly, in a study with many normal tissues, the expression of $\mathrm{Bcl}-\mathrm{x}_{\mathrm{L}}$ and $\mathrm{Bcl}-\mathrm{x}_{\mathrm{S}}$ was not observed in Schwann cells, neither in other cells from peripheral nerve sheath (Krajewski et al. 1994). However, in the already mentioned study of Park et al. (2013) with cell lines, the expression of Bcl- $\mathrm{x}_{\mathrm{L}}$ in normal Schwann cells could be detected by Western blot, but they presented lower expression when compared to Schwann cells derived from NF1-associated MPSNTs. Because the antibody we used does not distinguish the two isoforms of Bcl-x protein, we cannot know if the expression of $\mathrm{Bcl}-\mathrm{x}$ observed in the tumors of our study is referred to the anti or pro-apoptotic isoform. Nevertheless, it probably corresponds to $\mathrm{Bcl}-\mathrm{x}_{\mathrm{L}}$ isoform. 
Investigations with other malignant neoplasms demonstrated a correlation between high expression of $\mathrm{Bcl}-\mathrm{x}_{\mathrm{L}}$ protein with poor prognosis (Friess et al. 1998, Thamboo et al. 2006). Köhler et al. (2002) evaluated the expression of messenger RNA (mRNA) of Bcl- $\mathrm{x}_{\mathrm{L}}, \mathrm{Bcl}-2$ and other genes involved in apoptosis in 82 soft tissue sarcomas, including 15 MPNSTs. They concluded that high levels of mRNA of Bcl- $x_{L}$ were related to a poor prognosis. Unfortunately, this study, as many others, investigated a variety of histological types of soft tissue sarcomas together, and there is no report about the expression of these genes in each type of sarcoma separately. Our research did not show correlation of Bcl-x expression to the prognosis.

In our study, we performed the identification of apoptotic cells through the investigation of the presence of CC3 using IHC. The activation of effectors caspases, like caspase-3, is an event also known as "point of no return" of apoptosis, beyond which the cells certainly will entry to apoptosis (Asselin et al. 2001). The presence of CC3 has been demonstrated in many neoplasms, such as breast cancer, gliomas, neuroblastomas and sarcomas (Konstantinidou et al. 2007, Kobayashi et al. 2007, Matsubara et al. 2008, Nassar et al. 2008).

Double inactivation of NF1 gene in Schwann cells seems to be the common event in neurofibromas and MPNSTs. (Laycock-van Spyk et al. 2011) This leads to high levels of RasGTP, since neurofibromin, which is an important negative regulator of Ras pathway (similar to GTPase-activating protein - GAP) is deficient as a consequence of the NF1 gene mutation. It is known that Ras activation elicits antiapoptotic effects in many cells and that there is a positive correlation between neurofibromin deficiency and resistance to apoptosis (Dasgupta and Gutmann 2005, Guerrero et al. 2000, Shapira et al. 2007). Therefore, the observation that all neurofibromas and MPNSTs were immunopositive for $\mathrm{CC} 3$ in our study was unexpected. Interestingly, a study with cultured Schwann cells from a high-grade MPNST showed high levels of expression of caspase-3 gene (Lee et al. 2004).

The observation of the presence of CC3 in the nucleus and cytoplasm of MPNSTs cells in our study is in accordance with the results of a previous study (Kamada et al. 2005), which demonstrated that this protein is actively translocated, by one of more unknown proteins, from the cytoplasm to the nucleus. The reason why nuclear location of CC3 was only observed in MPNST and not in neurofibromas needs to be further investigated.

In the study with pancreatic neoplasms, using IHC technique and mRNA analysis, the pattern of cellular location of caspase-3 reflected the biological behavior of benign and malignant neoplasms (Satoh et al. 2000). Nuclear location of caspase-3 had statistically significance with the benign characteristic of pancreatic neoplasms, whereas the cytoplasmic location of this protein was correlated to the invasivity of malignant tumors. In some tumors, i.e. meningiomas (Konstantinidou et al. 2007), and Burkitt's and Burkitt-like lymphomas (Nomura et al. 2008), the location of caspase-3 protein has been shown to be a prognostic marker. In a study with 41 sarcomas, but none MPNSTs, the overall and disease free survival were lower in cases of patients with higher levels of CC3 (Matsubara et al. 2008).

Our results showed that high level of $\mathrm{CC} 3$ was associated to lower disease free survival. We found that the presence of cytoplasmic staining and high level of CC3 were more frequently associated to high-grade tumors and high mitotic index. Moreover, cytoplasmic location of CC3 was more common in MPNSTs from NF1 patients and high CC3 PI was associated to necrosis. These data show that higher quantities of $\mathrm{CC} 3$ are more common in tumors with more aggressive histological features and it is associated with a poor prognosis.

Because $\mathrm{CC} 3$ is associated to induction of apoptosis, it would be expected that tumors with high quantity of this protein would have better 
prognosis or more indolent features. Nevertheless, we should keep in mind that tumor growth results from lack of balance between proliferation and cell death by apoptosis and our results show that, in more aggressive tumors, although there was high number of apoptotic cells, there was also high number of proliferating cells (high mitotic index).

Finally, our study shows that apoptosis is altered in neurofibromas and mainly in MPNSTs and that the accumulation of Bcl-2, Bcl-x and CC3 may be correlated with the biology of these tumors. Further studies, including other members of Bcl-2 proteins family, such as Bax, Bak, Bad, are required for a better understanding of the alterations in apoptotic mechanisms involved in the biology of neurofibromas and MPNSTs.

\section{RESUMO}

OBJETIVOS: Estudar a expressão das proteínas Bcl-2, Bcl-x, assim como a presença da caspase-3 clivada em neurofibromas e tumores malignos da bainha do nervo periférico. A expressão de $\mathrm{Bcl}-2$ e $\mathrm{Bcl}-\mathrm{x}$ e a presença da caspases-3 clivada foram comparadas com as características clinicopatológicas dos tumores malignos da bainha do nervo periférico e seu impacto nas curvas de sobrevida também foi investigado. MATERIAIS E MÉTODOS: A avaliação das proteínas Bcl-2, Bcl-x e caspases-3 clivada foi realizada em 28 tumores malignos da bainha do nervo periférico e 38 neurofibromas, por imuno-histoquímica, utilizando microarrays de tecidos. A imunoquantificação foi realizada por análise computadorizada de imagem digital. CONCLUSÕES: A apoptose está alterada nos neurofibromas e principalmente em tumores malignos da bainha do nervo periférico. Altos níveis de caspase-3 clivada é mais comum em tumores com características histopatológicas mais agressivas e estão associados com baixa sobrevida livre de doença em indivíduos com tumor maligno da bainha do nervo periférico.

Palavras-chave: proteínas reguladoras da apoptose, tumor maligno da bainha do nervo periférico, neurofibroma, Neurofibromatose 1.

\section{REFERENCES}

Arai M, SASAKI A, SAIto N AND NAKAZATO Y. 2005. Immunohistochemical analysis of cleaved caspase-3 detects high level of apoptosis frequently in diffuse large B-cell lymphomas of the central nervous system. Pathol Int 55(3): 122-129.

Asselin E, MiLls GB AND TsANG BK. 2001. XIAP regulates Akt activity and caspase-3-dependent cleavage during cisplatin-induced apoptosis in human ovarian epithelial cancer cells. Cancer Res 61(5): 1862-1868.

Biroccio A, Benassi B, D’Agnano I, D’Angelo C, Buglioni S And MotTolese M. 2001. c-Myb and Bcl-x overexpression predicts poor prognosis in colorectal cancer: clinical and experimental findings. Am J Pathol 158(4): 1289-1299.

BRAY K, ChEN HY, KARP CM, MAY M, GANESAN S AND KARANTZA-WADSWORTH V. 2009. Bcl-2 modulation to activate apoptosis in prostate cancer. Mol Cancer Res 7(9): 1487-1496.

CUnHA KSG, Barboza EP AND DA FonseCA EC. 2003. Identification of growth hormone receptor in localised neurofibromas of patients with neurofibromatosis type 1 . J Clin Pathol 56(10): 758-763.

CUNHA KSG, BARBOZA EP AND DA FonseCA EC. 2008. Identification of growth hormone receptor in plexiform neurofibromas of patients with neurofibromatosis type 1 . Clinics 63(1): 39-42.

Cunha KSG, Caruso AC, De Faria PAS, Da Silva LE, Pires ARC AND GELLER M. 2012. Malignant peripheral nerve sheath tumors: clinicopathological aspects, expression of p53 and survival. Clinics 67(8): 963-968.

Cunha KSG, Caruso AC, GonÇALVES AS, Bernardo VG, PIRES ARC AND DA FONSECA EC. 2009. Validation of tissue microarray technology in malignant peripheral nerve sheath tumours. J Clin Pathol 62(7): 629-633.

DAN'URA T, KaWAi A, Morimoto Y, NAITO N, YoshidA A AND INOUE H. 2002. Apoptosis and expression of its regulatory proteins in soft tissue sarcomas. Cancer Lett 178(2): 167-174.

DAsGupta B AND GUTMANN DH. 2005. Neurofibromin regulates neural stem cell proliferation, survival, and astroglial differentiation in vitro and in vivo. J Neurosci 25(23): 5584-5594.

Ducatman BS, Scheithauer BW, Piepgras DG, Reiman HM AND ILSTRUP DM. 1986. Malignant peripheral nerve sheath tumors. A clinicopathologic study of 120 cases. Cancer 57(10): 2006-2021.

EISSA S AND SEADA LS. 1998. Quantitation of bcl-2 protein in bladder cancer tissue by enzyme immunoassay: comparison with Western blot and immunohistochemistry. Clin Chem 44(7): 1423-1429.

Friess H, Lu Z, ANDrÉN-SANDBERG A, BERberat P, ZIMMERMANN A AND ADLER G. 1998. Moderate activation of the apoptosis inhibitor bcl- $\mathrm{x}_{\mathrm{L}}$ worsens the prognosis in pancreatic cancer. Ann Surg 228(6): 780-787. 
Groeger AM, esposito V, De Luca A, CAssandro R, Tonini G AND Ambrogi V. 2004. Prognostic value of immunohistochemical expression of $\mathrm{p} 53$, bax, Bcl2 and $\mathrm{Bcl}-\mathrm{x}_{\mathrm{L}}$ in resected non-small-cell lung cancers. Histopathology 44(1): 54-63.

Guerrero S, Casanova I, Farré L, Mazo A, Capellà G AND MANGUES R. 2000. K-ras codon 12 mutation induces higher level of resistance to apoptosis and predisposition to anchorage-independent growth than codon 13 mutation or proto-oncogene overexpression. Cancer Res 60(23): 6750-6756.

Guo XZ, Shao XD, Liu MP, Xu JH, Ren LN and Zhao JJ. 2002. Effect of bax, bcl-2 and bcl- $x_{\mathrm{L}}$ on regulating apoptosis in tissues of normal liver and hepatocellular carcinoma. World J Gastroenterol 8(6): 1059-1062.

HIRAKAWA N, NAKA T, YAMAMOTO I, FUKUDA T AND TSUNEYOSHI M. 1996. Overexpression of bcl-2 protein in synovial sarcoma: a comparative study of other soft tissue spindle cell sarcomas and an additional analysis by fluorescence in situ hybridization. Hum Pathol 27(10): 1060-1065.

Hussein MR, Al-Badaiwy ZH AND Guirguis MN. 2004. Analysis of $\mathrm{p} 53$ and bcl-2 protein expression in the non-tumorigenic, pretumorigenic, and tumorigenic keratinocytic hyperproliferative lesions. J Cutan Pathol 31(10): 643-651.

Kamada S, KikKawa U, TSuJimoto Y AND HunTER T. 2005. Nuclear translocation of caspase- 3 is dependent on its proteolytic activation and recognition of a substrate-like protein(s). J Biol Chem 280(2): 857-860.

Kobayashi T, Masumoto J, Tada T, Nomiyama T, Hongo K AND NAKAYAMA J. 2007. Prognostic significance of the immunohistochemical staining of cleaved caspase-3, an activated form of caspase-3, in gliomas. Clin Cancer Res 13(13): 3868-3874.

KÖHLER T, WÜrl P, MEYE A, LAUTENSCHLÄGER C, BARTEL $\mathrm{F}$ AND BORCHERT S. 2002. High bad and bcl- $\mathrm{x}_{\mathrm{L}}$ gene expression and combined bad, bcl- $\mathrm{x}_{\mathrm{L}}$, bax and bcl-2 mRNA levels: molecular predictors for survival of stage 2 soft tissue sarcoma patients. Anticancer Res 22(3): 1553-1559.

Konstantinidou AE, Givalos $\mathrm{N}$, Gakiopoulou $\mathrm{H}$, Korkolopoulou P, Kotsiakis X AND BOVIATSIS E. 2007. Caspase- 3 immunohistochemical expression is a marker of apoptosis, increased grade and early recurrence in intracranial meningiomas. Apoptosis 12(4): 695-705.

KrajeWsKi S, KrajeWSKa M, SHabaik A, WANG HG, IRIE S AND FONG L. 1994. Immunohistochemical analysis of in vivo patterns of Bcl-X expression. Cancer Res 54(21): 5501-5507.

LAYCOCK-VAN SPYK S, THOMAS N, COOPER DN AND UPADHYAYA M. 2011. Neurofibromatosis type 1-associated tumours: their somatic mutational spectrum and pathogenesis. Hum Genomics 5(6): 623-690.

LeE PR, Cohen JE, Tendi EA, FArrer R, De VRIEs GH AND BECKER KG. 2004. Transcriptional profiling in an MPNST-derived cell line and normal human Schwann cells. Neuron Glia Biol 1(2): 135-147.
LEE SJ, PARK HJ, KIM YH, Kim BY, Jin HS AND KIM HJ. 2012. Inhibition of $\mathrm{Bcl}-\mathrm{x}_{\mathrm{L}}$ by ABT-737 enhances chemotherapy sensitivity in neurofibromatosis type 1-associated malignant peripheral nerve sheath tumor cells. Int J Mol Med 30(2): 443-450.

LeIter U, SCHMid RM, KASKel P, PETER RU AND KRÄHN G 2000. Antiapoptotic bcl-2 and bcl- $\mathrm{x}_{\mathrm{L}}$ in advanced malignant melanoma. Arch Dermatol Res 292(5): 225-232.

Matsubara T, Eimoto T, OKabe M, Miyabe S, Fujiyoshi Y AND Matsushita Y. 2008. Proliferation and apoptosis of tumour cells before and after neoadjuvant therapy for high-grade extremity sarcomas: divergent associations with tumour response and prognosis. Histopathology 52(6): 706-716.

Miettinen M, Sarlomo-RiKala M and Kovatich AJ. 1998. Cell-type- and tumour-type-related patterns of bcl-2 reactivity in mesenchymal cells and soft tissue tumours. Virchows Arch 433(3): 255-260.

NADLER Y, CAMP RL, GILTNANE JM, MOEDER C, RIMM DL AND KLUGER HM. 2008. Expression patterns and prognostic value of Bag-1 and Bcl-2 in breast cancer. Breast Cancer Res 10(2): R35.

NAssar A, Lawson D, Cotsonis G AND COHEN C. 2008 Survivin and caspase-3 expression in breast cancer: correlation with prognostic parameters, proliferation, angiogenesis, and outcome. Appl Immunohistochem Mol Morphol 16(2): 113-120.

Nomura Y, Yoshida S, KarUbe K, TAKEShita M, HiRose S AND NAKAMURA S. 2008. Estimation of the relationship between caspase-3 expression and clinical outcome of Burkitt's and Burkitt-like lymphoma. Cancer Sci 99(8): 1564-1569.

OfNer D, RieHEMANN K, MaIER H, RiedmanN B, NeHOdA H AND TÖTSCH M. 1995. Immunohistochemically detectable bcl-2 expression in colorectal carcinoma: correlation with tumour stage and patient survival. Br J Cancer 72(4): 981-985.

PAIK KH, PARK YH, RYOO BY, YANG SH, LEE JC AND KIM CH. 2006. Prognostic value of immunohistochemical staining of p53, bcl-2, and Ki-67 in small cell lung cancer. J Korean Med Sci 21(1): 35-39.

Park HJ, LeE SJ, Sohn YB, Jin HS, Han JH And Kim YB. 2013. NF1 deficiency causes $B c 1-x_{L}$ upregulation in Schwann cells derived from neurofibromatosis type 1 -associated malignant peripheral nerve sheath tumors. In J Oncol 42(2): 657-666.

SABAH M, Cummins R, LeAder M AND KaY E. 2007. Immunoreactivity of p53, Mdm2, p21(WAF1/CIP1) Bcl-2, and Bax in soft tissue sarcomas: correlation with histologic grade. Appl Immunohistochem Mol Morphol 15(1): 64-69.

SATOH K, KANEKO K, HiROTA M, TOYOTA T AND SHIMOSEGAWA T. 2000. The pattern of CPP32/caspase-3 expression reflects the biological behavior of the human pancreatic duct cell tumors. Pancreas 21(4): 352-357.

SCHEITHAUER BW, WOODRUFF JM AND ERLANDSON RA. 1999. Tumors of the peripheral nervous system. Washington, DC: Amer Registry of Pathology, $421 \mathrm{p}$. 
Schoelch ML, Le QT, Silverman S JR, McMillan A, DEKKER NP AND FU KK. 1999. Apoptosis-associated proteins and the development of oral squamous cell carcinoma. Oral Oncol 35(1): 77-85.

Shapira S, Barkan B, Friedman E, Fridman E, Kloog Y AND STEIN R. 2007. The tumor suppressor neurofibromin confers sensitivity to apoptosis by Ras-dependent and Rasindependent pathways. Cell Death Differ 14(5): 895-906.

Silvestrini R, Veneroni S, Daidone MG, Benini E, BORACCHI P AND MEZzETTI M. 1994. The Bcl-2 protein: a prognostic indicator strongly related to $\mathrm{p} 53$ protein in lymph node-negative breast cancer patients. J Natl Cancer Inst 86(7): 499-504.

Suster S, Fisher C AND Moran CA. 1998. Expression of bcl2 oncoprotein in benign and malignant spindle cell tumors of soft tissue, skin, serosal surfaces, and gastrointestinal tract. Am J Surg Pathol 22(7): 863-872.

Thamboo TP, TAN LHC AND TAN SY. 2006. Expression of Bcl-x in normal skin and benign cutaneous adnexal tumors. J Cutan Pathol 33(1): 27-32.

THANAKIT V, SHUANGSHOTI S AND RUANGVEJVORACHAI P. 2006. Expression of CyclinD1, p27kp-1, and bcl-2 in plexiform neurofibroma with and without malignant transformation in neurofibromatosis type 1. J Med Assoc Thai 89 Suppl 3: S53-57.
TSUTSUI S, YASUda K, SUZUKI K, TAKEUChI H, NishizaKI T AND Higashi H. 2006. Bcl-2 protein expression is associated with $\mathrm{p} 27$ and p53 protein expressions and MIB-1 counts in breast cancer. BMC Cancer 6: 187.

WATANABE T, ODA Y, TAMIYA S, MASUDA K AND TSUNEYOSHI M. 2001. Malignant peripheral nerve sheath tumour arising within neurofibroma. An immunohistochemical analysis in the comparison between benign and malignant components. J Clin Pathol 54(8): 631-636.

YANG H, SUN Y AND LIU F. 2000. [Expression of bcl-2 gene in relation to histologic type and grade, and prognosis of breast cancer]. Zhonghua Zhong Liu Za Zhi 22(6): 490-492.

Yoo J, Jung JH, LeE MA, Seo KJ, Shim BY AND Kim SH. 2007. Immunohistochemical analysis of non-small cell lung cancer: correlation with clinical parameters and prognosis. J Korean Med Sci 22(2): 318-325. 